\title{
Pemberdayaan kelompok tani kedelai melalui penerapan teknologi pengolahan kedelai untuk meningkatkan pendapatan petani di Desa Marga Mulya Kecamatan Rantau \\ Rasau
}

\author{
Lizawati ${ }^{(i)}$, Elis Kartika ${ }^{(\mathbb{D})}$, \& Made Deviani Duaja ${ }^{\mathbb{D}}$, Hajar Setyaji, \\ Gusniwati
}

Faculty of Agriculture, University of Jambi, Indonesia

* liza_wati@unja.ac.id

\begin{abstract}
The aim of the community service activiy is to increase farmers' knowledge and income in diversiying soybean processed products. This activity was carried out in Marga Mulya village, Rantai Rasau district, Tanjung Jabung Timur regecy which held from June until December 2019. The method used in this activity is giving education to society through the process of learning and implementation participatory (participatory learning and action), stages taken are; counseling on post-harvest technology for soybeans, practicing and implementing of making flour and soybean powder alongside with its processed products and enhancing packaging. Evaluation had done in the beginning of activity, the evaluation criteria are the number of attendance and the percentage of how active the member of farmers group in each stage. The result of this community service activity shows that most (80\%) of farmer group partner undestand and able to use soy processing tool and also to create variety of soybean processed product. It shows the increment of PKM business in achieveing diversiying processed soybean products, increaseing of processed production and product resilicence, as well as rising added value of processed soybean products.
\end{abstract}

Absrak Tujuan dari kegiatan pengabdian kepada masyarakat ini adalah meningkatkan pengetahuan petani dalam mendiversifikasi produk olahan kedelai serta meningkatkan pendapatan petani dari diversifikasi produk olahan kedelai. Kegiatan dilaksanakan di Desa Marga Mulya Kecamatan Rantau Rasau Kabupaten Tanjung Jabung Timur yang berlangsung dari bulan Juni sampai Desember 2019. Metode yang digunakan dalam kegiatan ini adalah pendidikan kepada masyarakat melalui proses belajar/praktik secara partisipatif (Participatory Learning and Action), tahapan yang dilakukan yaitu; penyuluhan teknologi pasca panen kedelai, pelatihan dan praktek pembuatan tepung dan bubuk kedelai serta produk olahannya dan perbaikan kemasan. Evaluasi dilakukan sejak awal kegiatan, kriteria evaluasi adalah jumlah kehadiran dan persentase keaktifan anggota kelompok tani pada setiap tahap kegiatan. Hasil dari kegiatan pengabdian ini memperlihatkan sebagian besar (80\%) mitra kelompok tani mengerti dan dapat menggunakan alat pengolahan kedelai serta mampu membuat aneka produk olahan kedelai. Peningkatan usaha mitra PKM yaitu terciptanya diversifikasi produk olahan kedelai, meningkatnya produksi produk olahan dan ketahanan produk serta meningkatnya nilai tambah produk olahan kedelai.

\section{O OPEN ACCESS}

Citation: Lizawati., E. Kartika., M. D. Duaja., H. Setyaji., Gusniwati. (2021). Pemberdayaan kelompok tani kedelai melalui penerapan teknologi pengolahan kedelai untuk meningkatkan pendapatan petani di Desa Marga Mulya Kecamatan Rantau Rasau. Riau Journal of Empowerment, 4(2), 59-68. https://doi.org/10.31258/raje.4.2.59-68

Received: 2019-12-19 Revised: 2021-07-03 Accepted: 2021-08-20

Language: Bahasa Indonesia (id)

Funding: Kementrian Riset Teknologi / Badan Riset Inovasi Nasional Republik Indonesia

ISSN 2623-1549 (online), 2654-4520 (print)

(c) 2021 Lizawati., Elis Kartika., Made Deviani Duaja., Hajar Setyaji., Gusniwati. Author(s) retain the copyright of article published in this journal, with first publication rights granted to Riau Journal of Empowerment. The article is licenced under Creative Commons Attribution 4.0 International License. This license permits unrestricted use, distribution, and reproduction in any medium, provided the original author and source are credited. 
Keywords: diversification; KWT; soybean; post-harvest; Rantau Rasau; technology

\section{PENDAHULUAN}

Kedelai merupakan salah satu komoditi pangan utama di Indonesia yang kebutuhannya terus meningkat. Komoditi kedelai mempunyai banyak fungsi, baik sebagai bahan pangan utama, pakan ternak maupun sebagai bahan baku industri skala besar hingga skala kecil atau rumah tangga. Rata-rata kebutuhan kedelai Indonesia setiap tahunnya mencapai 2,8 juta ton, produksi kedelai dalam negeri baru mampu memenuhi sekitar $40 \%$ dan kekurangannya $60 \%$ harus impor (Balai Penelitian Tanaman Aneka Kacang dan Umbi, 2015; Yulianti \& Edelina, 2019).

Prospek peningkatan produksi kedelai nasional masih terbuka lebar, diantaranya dengan perluasan areal tanam/panen. Rantau Rasau merupakan salah satu daerah sentra produksi kedelai di Provinsi Jambi. Luas tanam kedelai yang ada di Kecamatan ini adalah 1.429 ha. Kecamatan Rantau Rasau terletak di bagian timur Provinsi Jambi dengan luas wilayah $181 \mathrm{~km}$ persegi yang terdiri dari 10 desa. Jumlah penduduk Kecamatan ini adalah 11.688 jiwa. Sebanyak 8.261 jiwa (73\%) latar belakang pendidikan adalah Tamat SMP. Mata pencarian penduduk yang utama adalah bertani dan 60 persen adalah tanaman pangan yaitu padi, jagung dan kedelai (Badan Pusat Statistik, 2018).

Budidaya kedelai di Kecamatan Rantau Rasau pengelolaannya dilakukan secara manual, tidak menggunakan alat mesin pertanian, penggunaan sarana produksi minimal, dan skala usaha pada umumnya kecil serta sistem penanaman dilakukan dengan cara rotasi padi dan kedelai. Menurut Sumarno (2015), rotasi padi--kedelai merupakan "temuan teknologi asli petani" (indigenous technology), karena petani mampu mengidentifikasi niche agroekologi yang sesuai bagi tanaman kedelai.

Kecamatan Rantau Rasau merupakan salah satu daerah di Provinsi Jambi yang dilibatkan oleh Kementerian Pertanian dalam kegiatan Pengembangan Produsen Benih Kedelai (P3BK) guna menjamin penyediaan dan kebutuhan benih kedelai bersertifikat (Gayati, 2019). Varietas kedelai yang disalurkan pemerintah berupa varietas Anjasmoro, merupakan varietas unggul yang memiliki potensi hasil tinggi yaitu 2,03-2,25 t/ha, tahan rebah, polong tidak mudah pecah dan moderat terhadap karat daun sehingga varietas ini termasuk yang digemari oleh petani (Balitkabi, 2016; Heri et al, 2019). Akan tetapi petani masih kurang mengetahui tentang penanganan dan penyimpanan benih yang baik sehingga mereka tidak mempunyai stok benih yang baik yang akan digunakan apabila bantuan dari dinas terlambat atau tidak ada.

Permasalahan lain yang ditemui adalah pada setiap panen raya harga kedelai menjadi rendah yaitu $\mathrm{Rp} 4.000$ sedangkan jika tidak sedang musim panen harga kedelai di tingkat petani dapat mencapai $\mathrm{Rp}$ 7.000- $\mathrm{Rp}$ 9.000. Berdasarkan hal tersebut maka untuk meningkatkan nilai jual kedelai, kedelai bisa diolah lebih lanjut menjadi produk pangan yang bernilai jual lebih tinggi. Di Desa Marga Mulya pengolahan kedelai yang sudah ada adalah pembuatan tempe, tetapi belum bisa menyerap semua hasil limpahan panen kedelai. Oleh karena itu diversifikasi produk olahan kedelai yang lain agar hasil panen kedelai yang tidak terjual dapat dimanfaatkan dengan baik sehingga harga kedelai lebih stabil. Salah satu produk olahan kedelai yang potensial untuk di kembangkan adalah tepung kedelai. Tepung kedelai mengandung protein yang cukup tinggi dibanding tepung terigu dan harga tepung kedelai cukup tinggi yaitu $\mathrm{Rp} 35.000$ per kg. 
Mitra pengabdian tim PKM adalah masyarakat Desa Marga Mulya yang mata pencaharian utamanya adalah petani, dengan luas keseluruhan wilayah kurang lebih 3.479 ha, letak ketinggian dari permukaan laut 1-2 m. Jumlah penduduk Desa Marga Mulya sebanyak 985 jiwa dan 246 Kepala Keluarga (KK), terdiri dari 2 Dusun dan 9 RT dengan jarak tempuh ke

Lizawati et al. ibu kota kecamatan 4 km (Badan Pusat Statistik, 2019).

Rumusan masalah yang menjadi fokus kegiatan pengabdian kepada masyarakat ini adalah: bagaimana program penyuluhan, bimbingan dan demontrasi alat pengolahan kedelai menjadi tepung kedelai dan olahannya, serta perbaikan kemasan produk olahan kedelai dapat meningkatkan pendapatan petani. Adapun tujuan dari kegiatan pengabdian kepada masyarakat ini adalah meningkatkan pengetahuan petani dalam mendiversifikasi produk olahan kedelai serta meningkatkan pendapatan petani dari diversifikasi produk olahan kedelai

\section{METODE PENERAPAN}

Kegiatan pengabdian Program Kemitraan Masyarakat (PKM) ini dilakukan di Desa Marga Mulya Kecamatan Rantau Rasau dengan mitra binaan adalah kelompok tani kedelai Sri Mulyo. Pelaksanaan program kegiatan dilakukan dari bulan Juni sampai Desember 2019. Metode yang digunakan dalam kegiatan ini adalah pendidikan kepada masyarakat melalui proses belajar/praktik secara partisipatif (Participatory Learning and Action) yaitu kegiatan belajar secara berkelompok yang dilaksanakan secara interaktif dalam sutau proses kerja (Chambers, 1994, dalam Sururi et al, 2020). Tahapan kegiatan yang dilakukan adalah sebagai berikut:

\section{Penyuluhan tentang metode panen dan pasca panen kedelai sesuai SOP dan pengolahan Tepung kedelai}

Penyuluhan dilakukan dalam bentuk ceramah, untuk memudahkan dalam penyampaian materi maka digunakan infocus serta pemutaran video tentang metode panen dan pasca panen kedelai serta pengolahan tepung kedelai. Dalam kegiatan ini juga melibatkan peran aktif dari mitra untuk mengumpulkan anggota kelompok tani dan mempersiapkan tempat penyuluhan dan setiap kegiatan ini juga mengikut sertakan PPL setempat

\section{Bimbingan dan demontrasi alat pengolahan kedelai menjadi tepung kedelai dan olahannya}

Untuk bimbingan dan demontrasi alat pengolahan kedelai, terlebih dahulu dilakukan penyerahan alat pengolahan kedelai ke tim mitra. Peralatan yang diserahkan ke mitra dipilih yang pengoperasian lebih sederhana dan hemat listrik. Bahan yang akan diolah berupa kacang kedelai terlebih dahulu sudah disiapkan oleh mitra sesuai dengan prosedur yang telah disampaikan pada saat penyuluhan. Tepung kedelai yang telah dihasilkan lalu dibuat berbagai olahan kue basah seperti; soya keju, nastar, pudding dan berbagai macam produk lainnya.

\section{Perbaikan kemasan produk olahan kedelai}

Berbagai jenis produk yang telah dihasilkan mitra selanjutnya akan di kemas sesuai dengan SOP. Tujuan dari kegiatan ini adalah untuk memberikan wawasan dan pengetahuan kepada mitra PKM mengetahui fungsi, kegunaan dan jenis kemasan yang dapat diterapkan pada produk olahan kedelai, dapat memilih dan menghitung biaya pengemasan sesuai 
kebutuhannya serta dapat menerapkan kemasan yang sesuai dengan jenis produk, waktu, tempat dan biaya

\section{Evaluasi Kegiatan}

Evaluasi dilakukan sejak awal kegiatan, kriteria evaluasi adalah jumlah kehadiran dan persentase keaktifan anggota kelompok tani pada setiap tahap kegiatan. Tolak ukur dari keberhasilan penerapan PKM ini adalah lima puluh persen dari jumlah peserta hadir dan aktif dari awal kegiatan sampai tahap proses pengembangan produk serta keberlanjutan kegiatan. Data yang dikumpulkan adalah data primer diperoleh dari kelompok mitra dengan berpedoman pada kuisioner yang sudah disiapkan. Evaluasi kegiatan juga dilakukan dengan memberikan pre-test dan post-test kepada kelompok mitra, kemudian data dianalisis secara deskriptif dengan penyajian data menggunakan grafik.

\section{HASIL DAN KETERCAPAIAN SASARAN}

Sebelum dilakukan penyuluhan, terlebih dahulu dilakukan pertemuan dengan mitra yaitu ketua dan anggota kelompok tani untuk mensosialisasikan kegiatan Program Kemitraan Masyarakat (PKM) dan juga menentukan jadwal pelaksanaan kegiatan. Pada saat yang sama juga dilakukan kunjungan kelapangan guna melihat panen kedelai yang sedang dilakukan mitra PKM. Musim tanam kedelai di Desa Marga Mulya dilakukan pada awal bulan kering yaitu Mei dan Juni. Penyiapan lahan dilakukan dengan sistem tanpa olah tanah, untuk pembersihan lahan dilakukan dengan penggunaan herbisida dan terkadang juga dilakukan pembakaran. Menurut Jamal \& Jumakir (2011) bahwa wilayah Desa Marga Mulya adalah pasang surut yang dominan dengan tipe lahan sulfat masam potensial. Lahan pasang surut seperti ini sangat potensial untuk pengembangan kedelai. Adapun varietas kedelai yang dianjurkan salah satunya adalah Anjasmoro yang mampu beradaptasi dengan baik pada berbagai kondisi lahan.

Perbedaan umur panen antara daerah dataran tinggi dengan daerah dataran rendah sekitar 10-20 hari. Tujuan penanaman kedelai menentukan umur panen, dimana kedelai yang akan digunakan untuk bahan konsumsi dipanen pada umur 75-100 hari, sedangkan untuk dijadikan benih dipanen pada umur 100 - 110 hari (Pusat Pelatihan Pertanian, 2015). Petani kedelai di Desa Murga Mulya biasanya memanen kedelai jika sudah berumur 100 hari dengan ciri sebagian besar daun sudah menguning kecoklatan (Gambar 1).
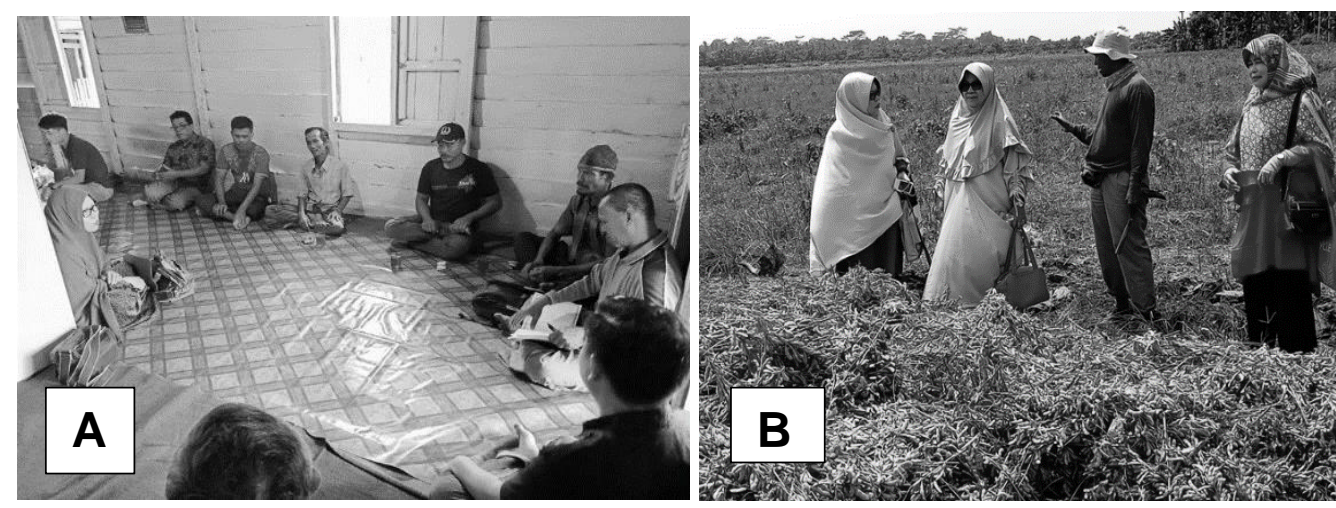

Gambar 1. (A) Sosialisasi Kegiatan PKM, dan (B) Tanaman kedelai mitra PKM yang sudah dipanen

Mutu dan produksi kedelai sangat dipengaruhi oleh penanganan panen dan pasca panen. Penanganan panen dan pasca panen yang tidak tepat atau tidak memenuhi syarat 
mengakibatkan mutu yang rendah dan kehilangan hasil, sehingga produksi berkurang. Dari hasil pantauan di lahan mitra terlihat bahwa pemanenan dilakukan tidak dengan hati-hati sehingga masih ada biji kedelai yang jatuh serta masih ada polong yang tertinggal. Untuk mengurangi kehilangan hasil panen maka pemotongan batang kedelai harus menggunakan sabit yang tajam dan Potong tanaman kedelai sedekat mungkin dengan pangkal batang agar tidak ada polong yang tertinggal (Pusat Pelatihan Pertanian, 2015).

Setelah dilakukan pemanenan, brangkasan kedelai ditumpuk begitu saja tidak segera dijemur. Keadaan seperti ini dapat menyebabkan turunnya mutu biji kedelai yang dihasilkan. Menurut Heri et al, (2019) bahwa brangkasan kedelai yang baru dipanen harus segera dijemur, jika tidak memungkinkan jangan tumpuk brangkasan, sedapat mungkin berdirikan brangkasan dalam ruangan. Keadaan ini memperlihatkan masih rendahnya adopsi teknologi ditingkat petani mitra. Menurut Ginting \& Tastra (2019) bahwa peningkatan produksi kedelai secara kuantitatif, baik melalui upaya intensifikasi dan ekstensifikasi, selayaknya diikuti oleh peningkatan mutu hasil panen karena akan berpengaruh terhadap harga jual biji kedelai.

Pemberdayaan masyarakat ini juga dilatar belakangi dengan permasalahan yang ada, dimana panen tahun 2019 lalu harga jual kedelai yang cukup rendah ditingkat petani, yaitu Rp4.000 per kg serta banyak ditemukan biji kedelai yang masih tidak memenuhi standar mutu untuk layak jual. Untuk itu diperlukannya suatu solusi yang dapat mengajak mitra perlunya pemahaman tentang pentingnya teknik panen dan pascapanen kedelai yang baik serta meningkatkan kesadaran mitra dan masyarakat terhadap pangan fungsional berbasis kedelai sebagai sumber pangan kaya protein. Mitra PKM masih perlu pendampingan dalam pascapanen dan diversifikasi olahan produk kedelai. Dengan demikian, solusi pemberdayaan kelompok tani kedelai adalah menerapkan teknologi pengolahan kedelai untuk meningkatkan pendapatan petani

Pelaksanaan program dilakukan dengan beberapa tahapan, yang pertama adalah kegiatan penyuluhan tentang penentuan waktu panen dan metode pascapanen kedelai sesuai SOP serta teknologi pengolahan tepung kedelai. Kegiatan penyuluhan dilaksanakan dirumah warga masyarakat yang dihadari oleh PPL, ketua dan sekretaris Gapoktan serta anggota kelompok tani kedelai yang beranggotakan lebih kurang 50 orang. Untuk memudahkan mitra dalam memahami materi penyuluhan yang disampaikan, maka setiap materi dibuatkan leafletnya serta penyampaian menggunakan infocus dengan gambar-gambar yang menarik. Saat dilakukan penyuluhan respon dari mitra cukup tinggi, dimana banyaknya pertanyaan yang diajukan saat dilakukan sesi tanya jawab (Gambar 3).
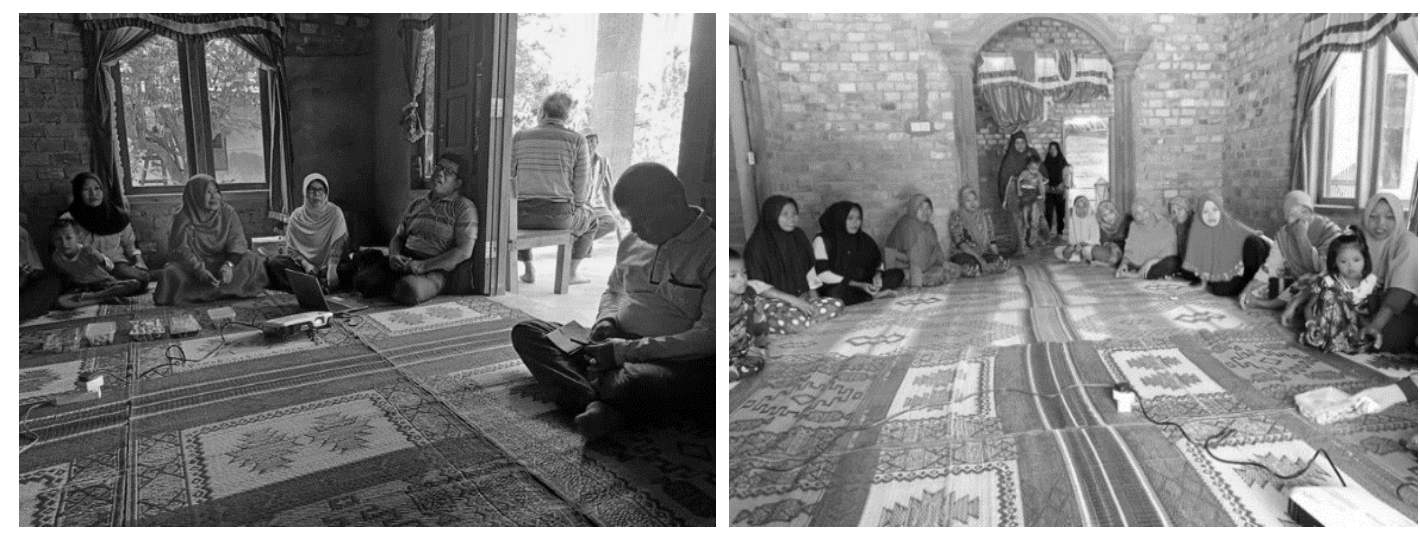

Gambar 3. Kegiatan Penyuluhan pasca panen dan cara pengolahan kedelai 
Kegiatan selanjutnya adalah bimbingan dan demontrasi alat pengolahan kedelai menjadi tepung yang dilanjutkan dengan memberikan contoh produk olahan tepung kedelai yang dapat dipasarkan. Saat dilakukan pelatihan pengolahan kacang kedelai menjadi tepung dan berbagai produk olahan berbahan dasar kedelai mitra memperhatikan dengan serius, terutama ibu-ibu dan remaja putri yang ada di Desa Marga Mulya, mereka sangat tertarik untuk melanjutkan kegiatan ini karena sebelumnya mitra hanya mengolah kacang kedelai menjadi tempe.

Pelaksanaan kegiatan selanjutnya, Tim PKM berperan sebagai fasilitator melalui metode Participatory Learning and Action (PLA) kepada masyarakat dengan membagi peserta menjadi tiga kelompok dan diberinama Kelompok Wanita Tani (KWT), yang masing-masing kelompok beranggotakan sebanyak tujuh sampai delapan orang. Setiap kelompok mendapatkan bantuan peralatan lengkap untuk pengolahan kedelai menjadi tepung dan bubuk kedelai (Gambar 4 dan 5).

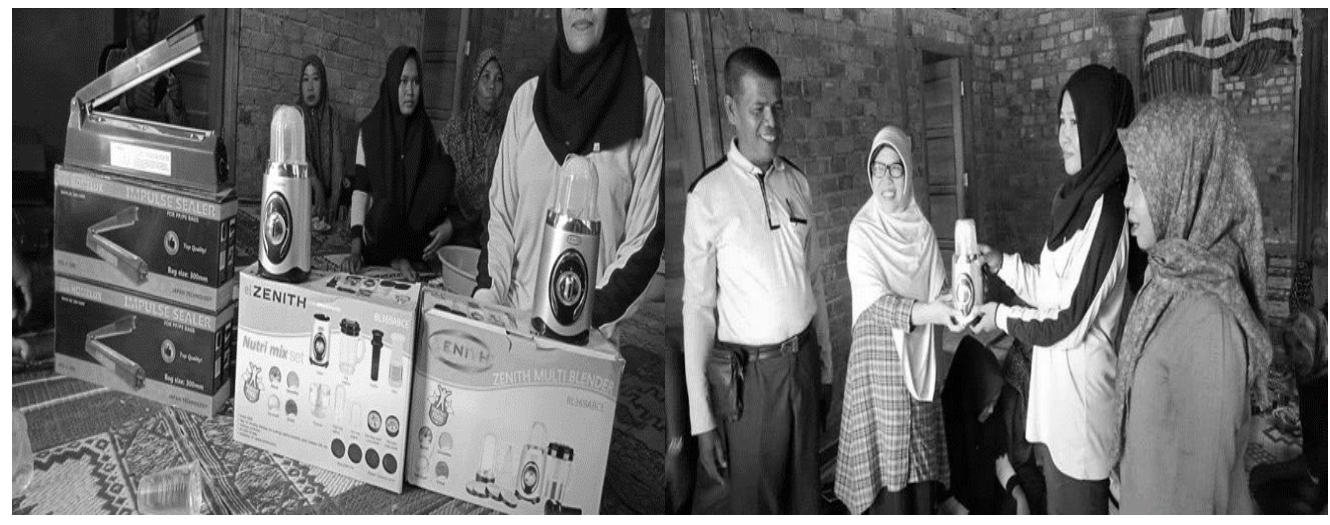

Gambar 4. Alat Pembuat tepung kedelai

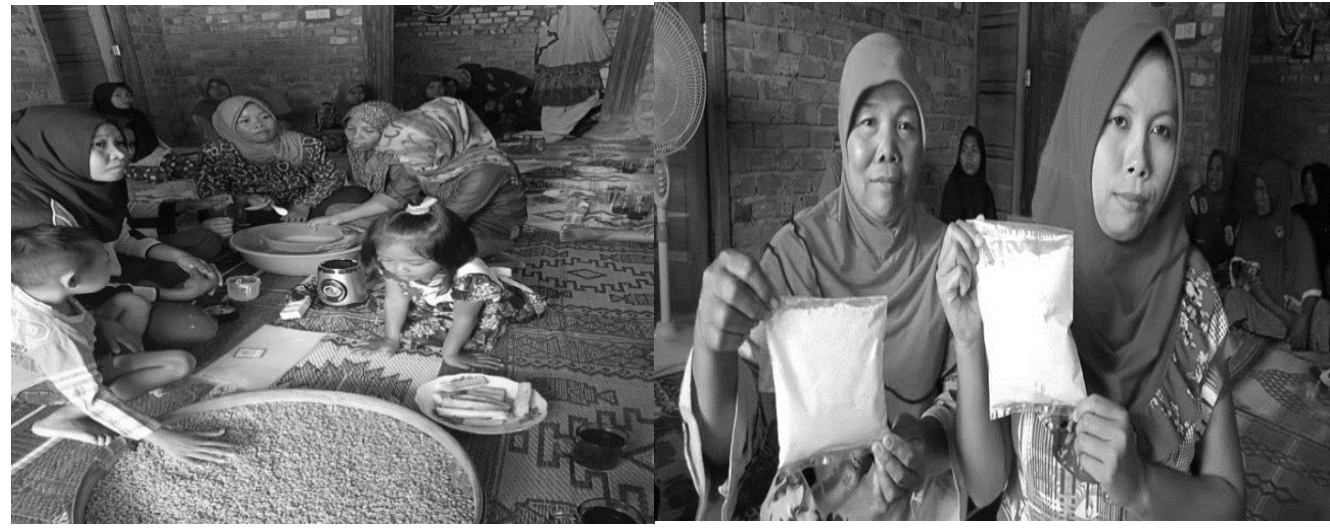

Gambar 5. Proses pembuatan tepung kedelai

Tepung dan bubuk kedelai dibuat melalui beberapa tahap proses perendaman, pembersihan, pencucian, penirisan penjemuran, penggilingan atau penumbukan, pengayakan, pengemasan, dan penyimpanan tepung kedelai (Rani et al, 2013). Untuk mendapatkan kualitas tepung kedelai yang halus dilakukan pengayakan menggunakan ukuran 100 mesh dan dapat dilanjutkan dengan ukuran 60 mesh jika mitra menginginkan bubuk kedelai. Menurut Widowati (2019) Istilah tepung kedelai digunakan jika kehalusan 100 mesh atau lebih, sedangkan bubuk untuk kehalusan 10-80 mesh.

Tepung kedelai memiliki banyak kegunaan dalam pemanfaatannya. Penepungan kedelai bermanfaat dalam menghemat biaya penyimpanan, mempermudah penyimpanan, dan mempermudah dalam pemanfaatan. Tepung kedelai merupakan bahan pangan setengah jadi 
yang dapat dijadikan sebagai tepung komposit dan sebagai bahan yang dapat memperkaya gizi dalam pangan berupa protein tinggi. Tepung merupakan salah satu bentuk alternatif produk setengah jadi yang dianjurkan, karena lebih tahan simpan, mudah dicampur (sebagai bahan komposit), dan lebih cepat dimasak sesuai tuntutan kehidupan modern yang serba praktis

Lizawati et al. (Damarjati et al, 2000). Kelompok Wanita Tani yang sudah mendapatkan bantuan alat pengolahan kedelai juga dibimbing bagaimana cara mengolah tepung kedelai menjadi berbagai produk makanan ringan yang bernilai jual tinggi.

Dalam beberapa bulan pendampingan selalu dilakukan evaluasi untuk melihat sejauh mana keseriusan dan keaktifan dari mitra dalam menjalankan program kegiatan yang telah disampaikan oleh Tim PKM, serta memanfaatkan alat dan bahan-bahan yang telah diserahkan. Hasil evaluasi memperlihatkan bahwa mitra mampu menghasilkan berbagai produk olahan kedelai lebih bervariasi baik dalam hal rasa maupun bentuk. Dimana masing-masing kelompok mampu menghasilkan 3 sampai 4 jenis kue yang berbahan dasar tepung kedelai, yaitu: kue bronis, kue emput dan kue nastar (Kelompok 1); kue gapit, kue susu, kue satu dan kue pastel (Kelompok 2); kue mentega, kue semprong dan kue nastar (kelompok 3). Dari hasil uji rasa dan survey pasar ternyata kue berbahan dasar tepung kedelai tersebut tidak kalah dengan produk kue lainnya, terutama untuk kue bronis, kue emput, kue gapit dan kue pastel lebih disukai (Gambar 6).

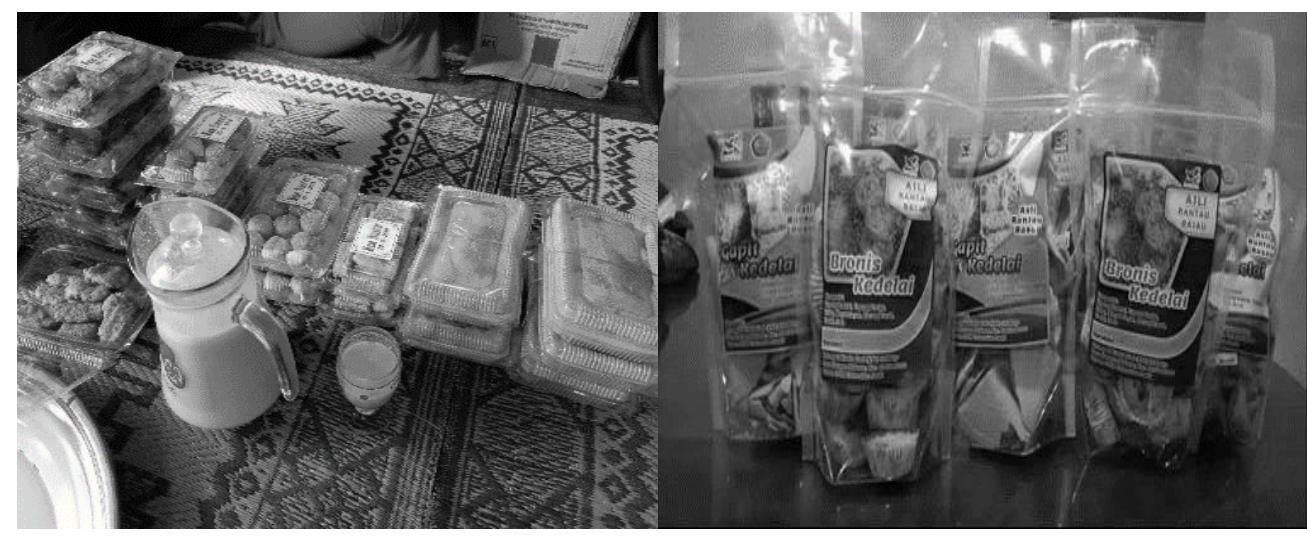

Gambar 6. Produk olahan tepung kedelai

Untuk meningkatkan daya simpan dan menambah kualitas dari produk makanan berbahan dasar kedelai, mitra juga diberikan bimbingan akan pentingnya pengemasan. Bahan kemasan harus memiliki beberapa sifat komersial agar dapat difungsikan dengan baik, yang antara lain: (1) Harus dapat mewadahi produk; (2) Harus dapat melindungi produk; (3) Harus dapat menjual produk dan (4) Biaya-biaya bahan pengemasan tersebut ditinjau secara keseluruhan adalah wajar dan otomatis (Departemen Perindustrian, 2007).

Program PKM memberikan dampak positif bagi kelompok mitra karena dirasakan adanya peningkatan ekonomi rumah tangga khususnya bagi kelompok wanita tani yang berada di Desa Marga Mulya khususnya bagi KWT. Keadaan mitra sebelum dan sesudah dilakukannya penerapan teknologi pengolahan tepung kedelai dapat dilihat pada Tabel 1.

Tabel 1. Perbaikan produksi dan peningkatan usaha mitra PKM

\begin{tabular}{llll}
\hline No & Urain Kegiatan & Sebelum Program PKM & \multicolumn{1}{c}{ Setelah Program PKM } \\
\hline 1. & Produk olahan & 1 produk (Tempe) & $>3$ produk \\
& kedelai & & $\begin{array}{l}\text { (Berbagai produk olahan tepung } \\
\text { kedelai) }\end{array}$ \\
\hline
\end{tabular}




\begin{tabular}{|c|c|c|c|}
\hline No & Urain Kegiatan & Sebelum Program PKM & Setelah Program PKM \\
\hline 2. & $\begin{array}{l}\text { Kapasitas } \\
\text { pengolahan kacang } \\
\text { kedelai }\end{array}$ & $2 \mathrm{~kg} / \mathrm{bulan}$ & $3 \mathrm{~kg} / \mathrm{minggu}$ \\
\hline 3. & Perbaikan kemasan & $\begin{array}{l}\text { Ketahan Produk 2-3 } \\
\text { minggu }\end{array}$ & Ketahan Produk 6-8 minggu \\
\hline 4. & Peningkatan harga & Rp 10.000/250 gram & Rp 20.000/250 gram \\
\hline 5. & Pemasaran & Tingkat Desa & Tingkat Kabupaten \\
\hline
\end{tabular}

Berdasar Tabel 1 di atas terlihat bahwa sebelum dilakukan program PKM umumnya mitra hanya mengolah hasil kedelai mereka menjadi tempe, dengan kapasitas pengolahan kacang kedelai yang masih rendah dan pemasarannyapun hanya tingkat desa bahkan terkadang hanya untuk komsumsi sendiri. Dengan adanya program pemberdayaan masyarakat ini, terlihat adanya peningkatan pengetahuan dan keterampilan mitra dalam hal diversifikasi produk olahan kedelai dan secara tidak langsung juga meningkatkan pendapatan rumah tangga mitra. Kacang kedelai yang diolah menjadi produk keripik tempe hanya dijual dengan harga Rp 10.000/250-gram sedangkan tepung kedelai yang telah diolah menjadi kue dijual dengan harga Rp 20.000/250-gram dengan ketahanan simpan 6-8 minggu sehingga dapat menjangkau pasar yang lebih luas.

Hasil evaluasi menunjukkan mitra sangat tertarik dengan program yang diberikan oleh Tim PKM, dimana setiap kegiatan mitra selalu hadir dalam jumlah yang cukup banyak yaitu lebih dari 25 orang dan selalu memberikan respon positif dengan banyaknya pertanyaan dalam setiap kegiatan dan selalu tanggap dalam mempersiapkan alat dan bahan yang dibutuhkan. Kondisi ini memperlihatkan tingginya partisipasi mitra PKM dalam penerapan teknologi yang disampaikan. Menurut Duaja et al, (2018) bahwa, partisipasi mitra merupakan unsur pokok pemberdayaan masyarakat dan merupakan salah satu faktor yang mempengaruhi keberhasilan suatu program. Hasil evaluasi program kegiatan yang telah dilakukan oleh Tim PKM dapat dilihat pada Gambar 7.

\section{Hasil Evaluasi Program Kegiatan}

Mitra mampu mengoperasikan alat pengolahan kedelai

Mitra kelompok tani mengerti dan mau melakukan kegiatan pasca panen sesuai dengan SOP Pengetahuan mitra tentang berbagai produk olahan kacang kedelai meningkat

Mitra berminat untuk membuat tepung kedelai

Mitra merasakan pelatihan pembuatan tepung kedelai bermanfaat

Mitra mau mencoba berbagai produk olahan tepung kedelai

Mitra mampu mengolah tepung kedelai menjadi berbagai produk makanan ringan

Mitra berminat menjadikan berbagai olahan kedelai sebagai peluang usaha

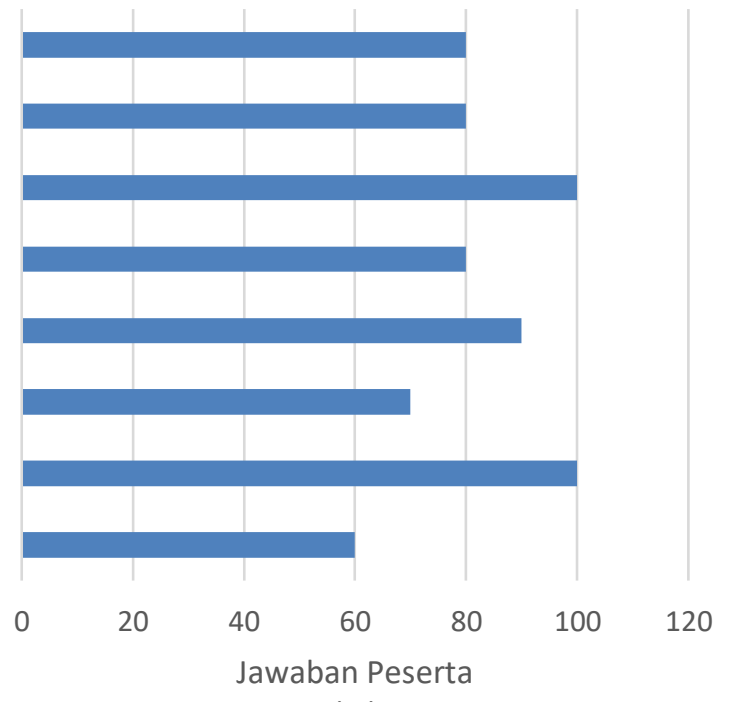

(\%)

Gambar 7. Hasil evaluasi program kegiatan pengabdian 
Berdasarkan Gambar 7, terlihat bahwa 80\% mitra kelompok tani mengerti dan mau melakukan kegiatan pasca panen sesuai dengan SOP. Untuk kegiatan pengolahan tepung kedelai ternyata $80 \%$ dari mitra juga mampu mengoperasikan alat pengolahan tepung kedelai yang diberikan oleh Tim pengabdian. $100 \%$ pengetahuan mitra tentang berbagai produk

Lizawati et al. olahan kacang kedelai meningkat dimana $80 \%$ dari mitra berminat untuk membuat tepung kedelai dan hanya $60 \%$ yang mau mencoba untuk membuat berbagai produk olahan tepung kedelai, hal ini disebabkan karena sebagian dari anggota KWT memiliki waktu yang cukup padat karena selain sebagai petani mereka juga juga punya pekerjaan sampingan. Dalam kegiatan ini juga dibuatkan kelompok usaha bersama dalam pengolahan tepung kedelai, ternyata $60 \%$ dari mitra berminat untuk menjadikan produk berbagai olahan tepung kedelai sebagai peluang usaha mereka. Selanjutnya agar produk olahan kedelai tersebut diminati konsumen maka strategi promosi dan pemasaran agar lebih ditingkatkan bersama dengan stakeholder terkait.

\section{KESIMPULAN}

Sebagian besar (80\%) mitra kelompok tani mengerti dan dapat menggunakan alat pengolahan kedelai serta mampu membuat aneka produk olahan kedelai. Peningkatan usaha mitra PKM dengan terciptanya diversifikasi produk olahan kedelai, meningkatnya produksi produk olahan dan ketahanan produk serta meningkatnya nilai tambah produk olahan kedelai.

\section{UCAPAN TERIMA KASIH}

Terimakasih disampaikan kepada Direktur Riset dan Pengabdian Masyarakat Kementerian Ristekdikti atas bantuan dana dalam pelaksanaan kegiatan pengabdian melalui skim Program Kemitraan Masyarakat (PKM), nomor: DIPA-042.06.1.40156/2019, tanggal 05 Desember 2018.

\section{Daftar Pustaka}

1. Balai Penelitian Tanaman Aneka Kacang dan Umbi. (2015). Panduan Teknis Budidaya Kedelai di Berbagai Kawasan Agroekosistem. Balai Penelitian Tanaman Aneka Kacang dan Umbi. Pusat Penelitian dan Pengembangan Tanaman Pangan. Badan Penelitian dan Pengembangan Pertanian.

2. Balai Penelitian Tanaman Aneka Kacang dan Umbi. (2016). Deskripsi Varietas Unggul Kedelai. http://balitkabi.litbang.pertanian.go.id/wp-content/uploads/2016/09/kedelai.pdf

3. Badan Pusat Statistik, (2018). Kabupaten Tanjung Jabung Timur dalam Angka 2018. Badan Pusat Statistik. Kabupaten Tanjung Jabung Timur. https://tanjabtimkab.bps.go.id/publication/2018/08/16/d76a5279f252da1ee21a4139/kabupatentanjung-jabung-timur-dalam-angka-2018.html

4. Badan Pusat Statistik, (2019). Kecamatan Rantau Rasau dalam Angka 2019. Badan Pusat Statistik. Kabupaten Tanjung Jabung Timur. https://tanjabtimkab.bps.go.id/publication/2019/09/26/9047bef757f415583e5f26ba/kecamatanrantau-rasau-dalam-angka-2019.html

5. Damardjati, D.S., Widowati, S., Wargiono, J \& Purba, S. (2000). Potensi dan Pendayagunaan Sumber Daya Bahan Pangan Lokal Serealia, Umbi-umbian, dan Kacang-kacangan untuk Penganekaragaman Pangan. Makalah pada Lokakarya Pengembangan Pangan Alternatif. Jakarta. 
6. Duaja, M, D., Buhaira, Nelyati, \& Kartika, E. (2018). Pemberdayaan Masyarakat Desa Sri Agung untuk Meningkatkan Ketahanan Pangan dengan Introduksi Padi Hitam di Pekarangan. Riau Journal of Empowerment, 1(1), 37-43. https://doi.org/10.31258/raje.1.1.5

7. Departemen Perindustrian. (2007). Pelatihan Kemasan. Direktorat Jenderal Industri Kecil Menengah. Jakarta. Retrieved from. https://kemenperin.go.id/download/141/Pelatihan-KemasanFlexible

8. Gayati, M.D. (2019, Agustus). Kementan Canangkan Program Pengembangan Produsen Benih Kedelai. Retrieved from. https://www.antaranews.com/berita/1012926/kementan-canangkanprogram-pengembangan-produsen-benih-kedelai

9. Ginting E., \& Tastra, I.K. (2019, Juni 7). Standar Mutu Biji Kedelai. Balai Penelitian Tanaman Kacang-kacangan dan Umbi-umbian, Malang. Retrieved from. http://balitkabi.litbang.pertanian.go.id/wp-content/uploads/2016/03/dele_19.erli_.pdf

10. Heri N, Yardha, \& Jumakir. (2019). Produksi dan Penyebaran Benih Kedelai Varietas Anjasmoro Mendukung Meningkatkan Produktivitas Kedelai di Provinsi Jambi. Agroecotenia, 2(1), 27-38. https://online-journal.unja.ac.id/Agroecotania/article/view/7903/9778

11. Jamal, H., \& Jumakir. (2011). Faktor Penentu Produktivitas Kedelai di Lahan Pasang Surut Kabupaten Tanjung Jabung Timur, Provinsi Jambi. Jurnal Pengkajian dan Pengembangan Teknologi Pertanian, 14(1), 49-61. http://dx.doi.org/10.21082/jpptp.v14n1.2011.p\%25p

12. Pusat Pelatihan Pertanian. 2015. Panen dan Pascapanen Tanaman Kedelai. Petunjuk Lapangan (PETLAP). Badan Penyuluhan dan Pengembangan SDM Pertanian.

13. Rani H, Zulfahmi, \& Widodo, Y.R. (2013). Optimasi Proses Pembuatan Bubuk (Tepung) Kedelai. Jurnal Penelitian Pertanian Terapan, 13(3), 188-196. https://doi.org/10.25181/jppt.v13i3.187

14. Sumarno. (2015). Perkembangan Teknologi Budidaya Kedelai di Lahan Sawah. Retrieved from. http://ejurnal.litbang.pertanian.go.id/index.php/ippan/article/download/2582/2222

15. Sururi A, Mulyasih R., \& Hasanah, B. (2020). Peningkatan Kapasitas Ekonomi Masyarakat melalui Pemberdayaan Kelompok Usaha Mikro Kecil Dan Menengah di Kawasan Pantai Utara Desa Domas Kabupaten Serang. Kumawula, 3(3), 405-415. https://doi.org/10.24198/kumawula.v3i3.27286

16. Widowati, S. (2019, November 17). Teknologi Pengolahan Kedelai. Balai Besar Penelitian dan Pengembangan Pascapanen Pertanian, Bogor. Retrieved from. http://balitkabi.litbang.pertanian.go.id/wp-content/uploads/2016/03/dele_21.widowati-1.pdf

17. Yulianti, A., \& Edelina, R.S. 2019. Analisis Perkembangan Harga Bahan Pangan Pokok di Pasar Domestik dan Internasional. Pusat Pengkajian Perdagangan dalam Negeri. Badan Pengkajian dan Pengembangan Perdagangan. Kementerian Perdagangan Republik Indonesia 